\title{
Renal Abscess
}

National Cancer Institute

\section{Source}

National Cancer Institute. Renal Abscess. NCI Thesaurus. Code C123017.

An abscess that is located within the renal parenchyma. 